\title{
FEATURES OF THE PROCESS OF DEHYDRATION OF FUNCTIONAL VEGETABLE RAW MATERIALS
}

\section{Zhanna Petrova ${ }^{1}$ Yurii Sniezhkin ${ }^{2}$}

DOI: https://doi.org/10.30525/978-9934-26-021-6-38

Abstract. Given the general trend of energy consumption, which leads to an increase in the amount of energy consumed worldwide, the cost of this energy is constantly increasing and its deficit is growing. Therefore, it is important to solve the problem of creating and large-scale implementation of modern energy-efficient heat technologies that reduce energy. This is especially true for providing the population to food, as an additional complication is that the production and processing of agricultural raw materials occurs in conditions of increased consumption of gas and other energy sources with low coefficient of performance and high losses of raw materials during processing. Food and nutrition play a leading role in everyone's life, no matter how we treat it. Nutrition is a key moment in the life of every living organism. Functional foods have evolved as a separate category and are not always considered as dietary supplements. Functional food products (FFP) are the products influencing a functional condition of an organism for the purpose of its increase - resistance, working capacity, prolongation of life. Although the definitions of functional products are different, they are basically ordinary foods and beverages, but enriched with a functional component - a nutrient that plays a special physiological role in the body, has a positive effect on human health.

The purpose of the paper is a theoretical and experimental substantiation of complex and efficient processing of vegetable raw materials, creation of energy-efficient heat technology of agricultural raw materials processing

\footnotetext{
${ }^{1}$ Doctor of Engineering, Chief Researcher of Department of the Heat and Mass Transfer in Heat Technologies, Academician Ukrainian Academy of Sciences, Institute of Engineering Thermophysics of National Academy of Sciences of Ukraine, Ukraine ${ }^{2}$ Academician of NAS of Ukraine, Director, Institute of Engineering Thermophysics of National Academy of Sciences of Ukraine, Ukraine
}

(C) Zhanna Petrova, Yurii Sniezhkin 
in order to obtain functional products with maximum preservation of biologically active substances.

In this work, 4 groups of functional foods were studied (according to the classification of the main plant functional ingredients of Doctor of Technical Sciences Petrova Zh.O.) - these are antioxidants, phytoestrogens, folates, prebiotics. An important point is to increase energy efficiency with maximum preservation of functional ingredients of raw materials. Preliminary preparation of raw materials for drying was developed and researched, optimal dehydration regime parameters were selected, which allow to reduce energy consumption for the process and to keep BAS for each group of functional raw materials at a high level.

Since the increase in energy costs for drying is associated with the difficulty of removing moisture from plant material, it was important to investigate changes in the specific heat of evaporation of water from functional compositions. The conducted experimental researches confirmed the theoretical assumption of dependence of specific heat of evaporation of water from parenchymal fabrics of plants on composite components of raw materials. The obtained results allow to state that at correctly picked up compositions they not only stabilize components of native raw materials, but also there is an intensification of drying process with reduction of energy consumption on process. The duration of the drying process of functional raw materials on the experimental convective stand was calculated by the method of Krasnikov V.V. The estimated drying durations of functional raw materials and drying rates are determined. The kinetics of heat exchange was studied with the determination of the specific heat flux density and the Rebinder number, which proves the efficiency of the introduction of step drying regimes.

\section{Introduction}

There is a global increase in vegetable and fruit production. But the number of losses as a result of injuries during the collection, transportation and storage of these products is also growing. According to research by leading scientists of the world up to $20-30 \%$ of grown vegetables and fruits do not reach the final consumer and this figure is growing. If vegetables and fruits are sold fresh, they must be properly calibrated, and those that do not have the appropriate standards are considered unconditioned (irregularly 
shaped, large or small). Many used plant products lose their physical, chemical and sensory characteristics within a few days after harvest, especially if they are stored in adverse environmental conditions. Postharvest processing of vegetables and fruits can help reduce their losses, ease of consumption, savings in daily cooking, which is quite relevant in today's world.

Given the general trend of energy consumption, which leads to an increase in the amount of energy consumed worldwide, the cost of this energy is constantly increasing and its deficit is growing. Therefore, it is important to solve the problem of creating and large-scale implementation of modern energy-efficient heat technologies that reduce energy.

As the food industry develops and the material well-being of the population grows, the requirements for food ingredients increase. Food producers are not looking for the cheapest, but the most natural and highquality raw materials and ingredients. Physiologically normal nutrition is the provision of the necessary amount of energy from food components (mainly carbohydrates and fats), full consumption of essential amino acids (in the form of protein), essential fatty acids, vitamins and minerals. For normal growth and metabolism, the human body must regularly receive each biological and physiological component with food. If the intake of any food component is disturbed, it leads to physiological disorders and diseases. Excess nutrients can also cause malaise.

Processing of agricultural raw materials for the production of functional foods is a complex energy-intensive technological processes with high requirements for the final product. That is, in each case it is necessary to solve a problem of preservation of nativeness of raw materials and simultaneous observance of criteria of safety, terms of storage, manufacturability in the further use.

\section{Relevance and existing research}

Currently, the range of new foods is quite diverse, it will expand in the future. Nutritional ingredients have not only nutritional value but also biological activity. They are usually offered as raw materials for the production of functional products and healthy foods. Therefore, it is necessary to study not only biological activity, but also the technological properties of functional plant ingredients, which allows to reduce the cost 
of production, expand its range, improve product quality and facilitate the technological process.

Many modern foods are deprived of many biologically active ingredients due to refining, distillation, recrystallization, canning and other technological processes. It should be noted that not only technological processing impoverishes natural products with biologically active substances. Some crops are genetically imperfect because they contain few important biologically active substances. To reduce the usefulness of natural products also leads to their cultivation in adverse conditions.

One of the main tasks in the near future is to increase the bioavailability of functional ingredients. In the future, nanostructured products or whole systems of active ingredient additives, such as molecular encapsulation, will appear. Existing functional products will be enriched with other products, such as confectionery - caramel, chewing gum $[1 ; 2]$. Further growth of the functional products market is expected.

\section{Materials and methods of research}

Research materials - functional (antioxidant, phytoestrogenic, prebiotic, folate) plant raw materials. To assess the quality of functional products used standard research methods using the methods of spectroscopy, electron microscopy $[2 ; 3]$.

During the research, experimental methods were used using modern means of measuring drying parameters: experiment time, coolant temperature and material weight reduction using an automated system for collecting and processing information in the developed program «Sooshka», on specially designed and manufactured installations. For processing of the received data methods of mathematical calculation of experiment were used, and the received data were processed in modern integrated systems Excel and Mathcad. Theoretical research was conducted using methods based on the basic provisions of the theory of heat and mass transfer, the theory of similarity, processed using computer technology.

\section{Research results}

\subsection{Preliminary preparation of functional raw materials for drying}

Difficulties in drying vegetable raw materials are due to the fact that under the influence of heat treatment, light, oxygen, $\mathrm{pH}$, losses of up to $90 \%$ 
of carotenoids, betanin, folate, phytoestrogens and other biologically active substances. Therefore, to determine the most promising ways of processing functional raw materials, the effect of pre-treatment on the raw material to be dried has been studied.

Carrots are the basis of antioxidant raw materials, which include carotenoids, which in the presence of lipids and proteins are converted in the human body into vitamin A.

It is known that previous studies of changes in the content of carotenoids in the blanching of carotene-containing raw materials have unstable indicators. Our studies on hygrothermal treatment have shown that during blanching according to the developed regimes there is almost no loss of carotenoids, but only their mechanical leaching in the tissue section [2; 4].

Presented in Figure 1 the results of preparation of antioxidant raw materials (based on carrots) for drying showed that carrots without prior preparation during drying loses up to $44 \%$ of carotenoids (pos. 1 ). Developed modes of preparation of mono-raw materials allowed to reduce these losses to $12 \%$ (pos. 2). Developed methods of preparation of antioxidant raw materials for drying made it possible to reduce the loss of carotenoids during drying by $4.4-5.1 \%$ (pos. 4,5).

The proposed energy-efficient method of pre-treatment of antioxidant compositions based on legumes and carrots eliminates the hygrothermal treatment of carrots (steam treatment). This made it possible to reduce the loss of carotenoids during drying by 10 times.

Substances that have antioxidant properties also include water-soluble pigments betalaine. In red beetroot, $90 \%$ of them are represented by betanine, the losses of which were investigated during processing $[5 ; 6]$.

Betanine is not resistant to temperature and $\mathrm{pH}$, heat treatment destroys it up to $80 \%$. To stabilize betanine during processing, modes of preparation of betanine-containing raw materials for drying have been developed [7].

The losses of betanine during drying without prior preparation of raw materials, with hydrothermal treatment of whole roots in an acidified environment, beet composition in the appropriate ratios with rhubarb and lemon to create the optimal $\mathrm{pH}$ were studied (Figure 2).

As can be seen from Figure 2, the loss of betanine during drying, without prior preparation of raw materials is $66 \%$ (mark 1). Our pre-treatment technology, which involves cooking whole roots with the selected optimal 
Zhanna Petrova, Yurii Sniezhkin

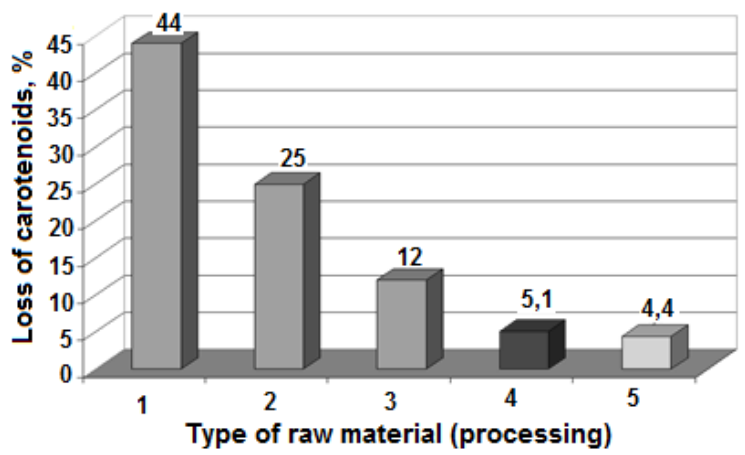

Figure 1. Hygrothermal treatment of antioxidant raw materials: 1 - carrots without hygrothermal treatment, 2 - carrots with existing technology of hygrothermal treatment, 3 - carrots with developed hygrothermal treatment, 4 - oat-carrot raw materials hygrothermally treated, 5 - hygrothermal treatment of celery-carrot raw materials

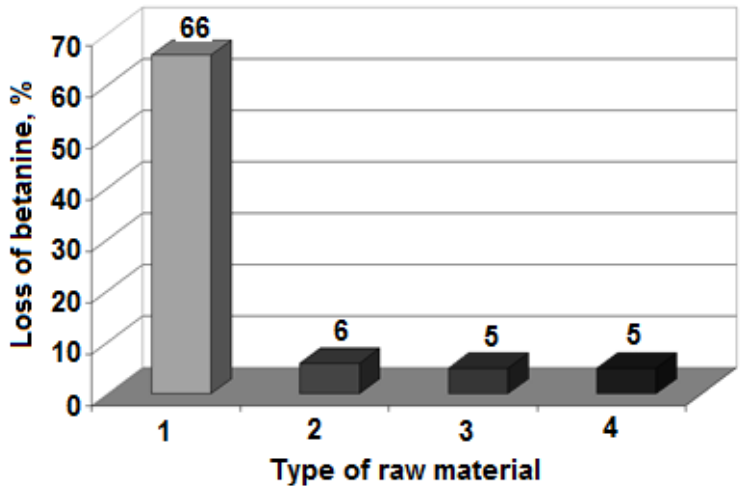

Figure 2. Losses of betanine from the method of preparation of raw materials for drying: 1 - beets without hydrothermal treatment, 2 - hydrothermally treated beets; 3 - rhubarb beet (blending), 4 - lemon beet (blending)

acidic environment, makes it possible to reduce the loss of betanine to $6 \%$ (pos. 2), but it is quite energy-intensive process. An energy-efficient method of preparation of antioxidant raw materials before drying with complete 
replacement of heat treatment by blending has been developed. The loss of betanine is up to $5 \%$ (pos. 4.5 ).

The developed methods of preparation of beta-containing raw materials made it possible to preserve betanin by $95 \%$ and reduce energy losses during the preparation of raw materials by $75 \%$ [2].

The basis of phytoestrogenic raw materials is soy due to its content of isoflavones. High fat content reduces the shelf life of shredded soybeans due to oxidation of fats, which leads to the destruction of other nutrients. To prevent fat oxidation, soybeans were combined with carrots, pumpkin, beets and onions. The proposed compositions reduce the oxidation of fats and allow to preserve valuable biologically active substances that contain soybeans and vegetables.

The developed preparation of phytoestrogenic raw materials for drying provides such processes as soaking in water of whole soybeans at optimum temperatures and their cooking with the subsequent mixing and crushing, excluding thus separate hygrothermal processing of carrots.

In the course of researches the chemical composition of soybeans before and after hygrothermal processing was defined (Figure 3 ). The quality of raw materials before and after preparation was evaluated by the content of mass fraction of total nitrogen, soluble carbohydrates, lipids, digestibility

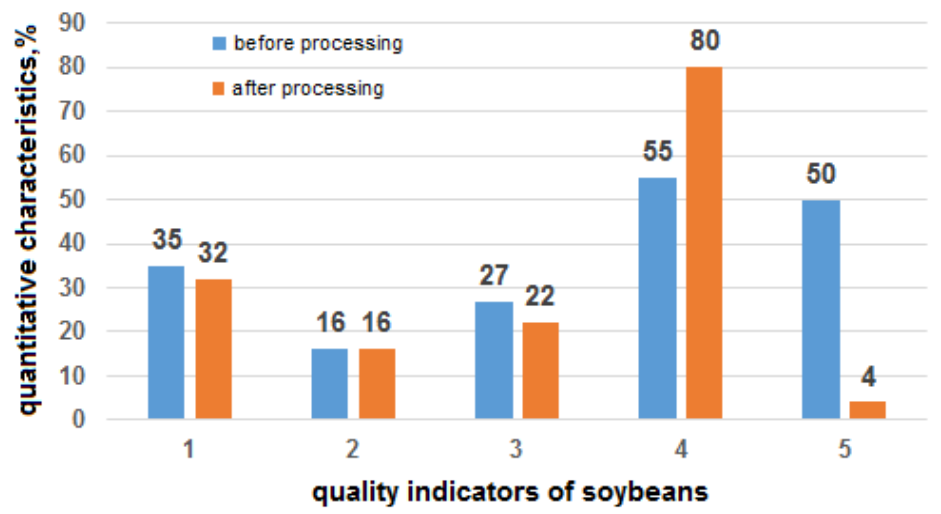

Figure 3. The effect of heat treatment on the quality of soybeans:

1 - nitrogenous substances, 2 - lipids, 3 - carbohydrates, 4 - digestibility, 5 - trypsin inhibitor 
of proteins and trypsin inhibitor. After hygrothermal treatment soy loses up to $3 \%$ of nitrogenous substances, up to $5 \%$ of soluble carbohydrates. These substances pass into water during hygrothermal treatment, lipids remain unchanged. But after hygrothermal treatment, protein digestibility increases by $25 \%$, and trypsin inhibitor is almost completely inactivated. The obtained results allowed to develop rational modes of preparation of phytoestrogenic raw materials for drying [8].

Functional raw materials containing folate were studied. It is known that during storage and heat treatment, the loss of folate in folate-containing raw materials is $50-70 \%$. To reduce folate losses, folate-containing raw materials were combined with raw materials with a high content of vitamin C. Folate-based compositions are based on green peas, asparagus beans, spinach [9].

Hygrothermal treatment of folate-containing raw materials involves blanching of green peas, asparagus beans with mild soaking in spinach water. At such modes there are minimal losses of vitamins and other biologically active substances. After preliminary preparation to folatecontaining raw materials we add vegetables with the high content of ascorbic acid. This allowed to reduce folate losses by $20-25 \%$ during drying.

To obtain prebiotic functional compositions used raw materials with a high content of dietary fiber. Prebiotic compositions differ in the content of pectin substances up to $30 \%$. During heat treatment in the presence of soluble carbohydrates and organic acids there is a redistribution of insoluble and soluble forms of pectin, protopectin partially turns into soluble form and this, as studies have shown, slows down the drying process by $15-20 \%$. Therefore, it is not advisable to carry out pre-heat treatment of prebiotic compositions [10].

In order to preserve and increase the functionality of antioxidant, phytoestrogenic, folate-containing and prebiotic properties of plant raw materials, conditions for stabilization of functional ingredients were developed (Table 1).

The developed preliminary processing of functional raw materials allows to reduce losses of useful substances, to increase their food quality, to reduce energy expenses by excluding long action on raw materials of steam or hot water. 
Table 1

Stabilization of functional ingredients of vegetable raw materials

\begin{tabular}{|c|c|c|}
\hline Vegetable raw materials & Functional ingredients & $\begin{array}{c}\text { Pre-processing of raw } \\
\text { materials }\end{array}$ \\
\hline $\begin{array}{l}\text { Antioxidants based on } \\
\text { carotenoids: } \\
\text { 1. Bean and carrot, } \\
\text { 2. Pea and carrot, } \\
\text { 3. Oat and carrot, } \\
\text { 4. Celery and carrot }\end{array}$ & $\begin{array}{l}\text { Carotenoids, lipids, } \\
\text { proteins, vitamin E, } \\
\text { spicy-aromatic } \\
\text { substances }\end{array}$ & $\begin{array}{l}\text { Hygrothermal treatment, } \\
\text { blending of raw materials } \\
\text { to prevent enzymatic and } \\
\text { non-enzymatic Browning }\end{array}$ \\
\hline $\begin{array}{l}\text { Antioxidants based on } \\
\text { betanine: } \\
\text { Red beetroot and rhubarb } \\
\text { Red beet-lemon }\end{array}$ & $\begin{array}{l}\text { Betanine, oxalic acid of } \\
\text { rhubarb, lemon acid of } \\
\text { lemon }\end{array}$ & $\begin{array}{l}\text { Blending of raw materials } \\
\text { to create an acidic } \\
\text { environment }\end{array}$ \\
\hline $\begin{array}{l}\text { Phytoestrogenic: } \\
\text { Soybean-carrot } \\
\text { Soybean and pumpkin } \\
\text { Soybean red beetroot } \\
\text { Soybean and onion } \\
\text { Rape and carrot } \\
\text { Pear and apple } \\
\text { Pear and zucchini }\end{array}$ & Phytoestrogens & $\begin{array}{l}\text { Hygrothermal treatment, } \\
\text { blend to prevent fat } \\
\text { oxidation, inactivation } \\
\text { antitrypsin }\end{array}$ \\
\hline $\begin{array}{l}\text { Folate-containing: } \\
\text { Spinach and apple } \\
\text { Banana-apple } \\
\text { Nettle and apple } \\
\text { Green peas and zucchini } \\
\text { Potato and carrot } \\
\text { Celery leaf-apple } \\
\text { Asparagus beans - onions }\end{array}$ & Folate, ascorbic acid & $\begin{array}{l}\text { Hygrothermal treatment, } \\
\text { blend to stabilize folate } \\
\text { during drying }\end{array}$ \\
\hline $\begin{array}{l}\text { Prebiotic: } \\
\text { Apple pulp and pear } \\
\text { Apple pulp and zucchini } \\
\text { Citrus pulp and apple } \\
\text { Grape pulp and beets } \\
\text { Beet pulp and apple } \\
\text { Zucchini and apple }\end{array}$ & Dietary fiber & $\begin{array}{l}\text { Blending to improve } \\
\text { organoleptic characteristics } \\
\text { to prevent clumping and } \\
\text { adhesion }\end{array}$ \\
\hline
\end{tabular}

\subsection{Dehydration of functional raw materials}

Studies of drying kinetics were performed on an experimental drying stand in a wide range of operating parameters, the temperature varied in the range of $50-100^{\circ} \mathrm{C}$, speed $1.5-3.5 \mathrm{~m} / \mathrm{s}$, layer thickness 
2-20 $\mathrm{mm}$ and moisture content dry air $7-15 \mathrm{~g} / \mathrm{kg}$, with continuous automatic collection and processing of information about the change of mass, temperature of the sample using the developed application program. The developed application program «Sooshka» allows to carry out calculations with construction of curves of drying and speed of drying.

Drying curves of antioxidant, phytoestrogenic, folate-containing and prebiotic raw materials have the appearance characteristic of colloidal capillary-porous materials. Studies on the drying of, for example, the antioxidant pea-carrot mixture in the temperature range of the coolant from 60 to $100^{\circ} \mathrm{C}$ showed (Figure 4, a) that the duration of drying the material in the coolant mode $100^{\circ} \mathrm{C}$ is reduced by 2.25 times compared to $60^{\circ} \mathrm{C}$.

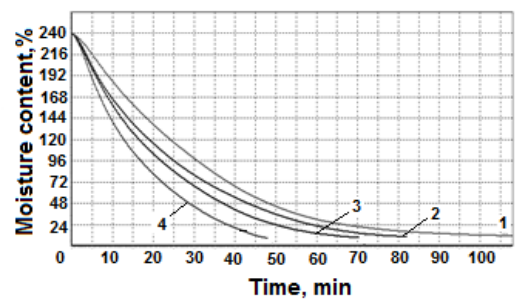

a)

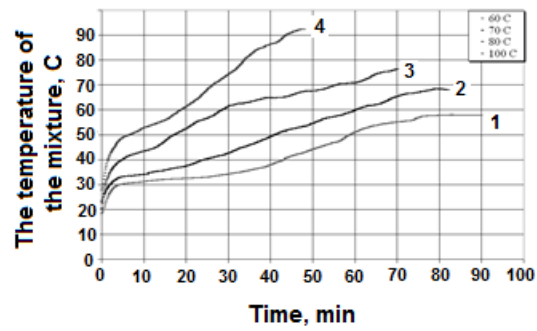

b)

Figure 4. The influence of coolant temperature on the drying process of pea-carrot composition in the layer $\delta=10 \mathrm{~mm}$ to $V=3.5 \mathrm{~m} / \mathrm{s} ; d=10 \mathrm{~g} / \mathrm{kg} \mathrm{dr}$. a.: $1-60^{\circ} \mathrm{C}, 2-70^{\circ} \mathrm{C}, 3-80^{\circ} \mathrm{C}, 4-100^{\circ} \mathrm{C}$

The heating intensity of the material is higher at a temperature of $100^{\circ} \mathrm{C}$ and is $92^{\circ} \mathrm{C}$, which is 2.2 times higher than the temperature of $60^{\circ} \mathrm{C}$ (Figure $4, \mathrm{~b}$ ). The use of high-temperature coolant to intensify the process is limited by the quality of the material.

In Figure 5 presents the results of the effect of coolant temperature during drying of antioxidant raw materials on the preservation of carotenoids. The created composition have losses of carotenoids in comparison with monoraw materials less by $3-6 \%$. 


\section{Chapter «Engineering sciences»}

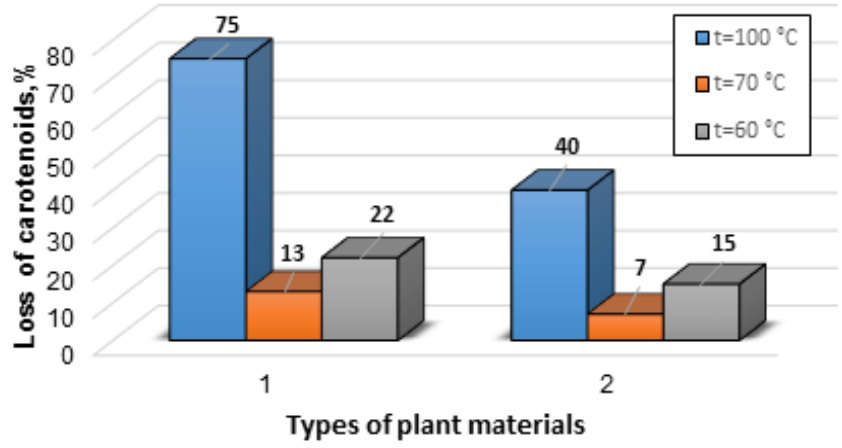

Figure 5. Loss of carotenoids during drying of antioxidant raw materials depending on the coolant temperature:

$$
1 \text { - carrot; } 2 \text { - pea-carrot }
$$

Antioxidant raw materials include red beetroot with a high content of betanine. Therefore, the study of drying kinetics was performed on the composition of beet-lemon.

The kinetics of the drying process of the red beetroot-lemon composition is shown in Fig.6. With increasing coolant temperature from $60^{\circ} \mathrm{C}$ to $100^{\circ} \mathrm{C}$, the drying time of the red beetroot-lemon composition decreases 1.7 times (Figure 6, a).

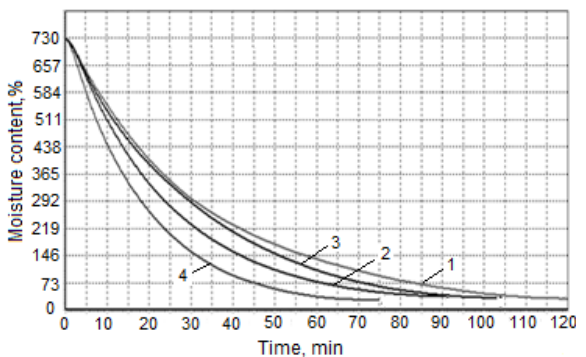

a)

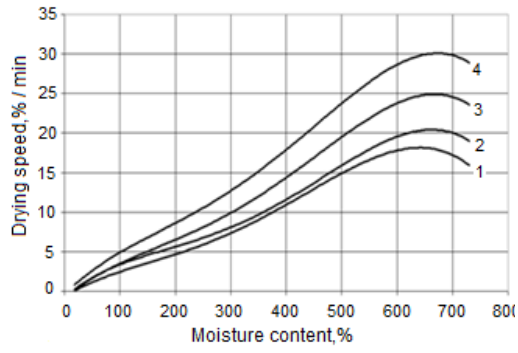

b)

Figure 6. The influence of coolant temperature on the drying process of the red beetroot-lemon composition in the layer

$$
\begin{gathered}
\delta=10 \mathrm{~mm} \text { to } V=3.5 \mathrm{~m} / \mathrm{s} ; d=10 \mathrm{~g} / \mathrm{kg} \mathrm{dr} \text {. a.: } \\
1-60^{\circ} \mathrm{C}, 2-70^{\circ} \mathrm{C}, 3-80^{\circ} \mathrm{C}, 4-100^{\circ} \mathrm{C}
\end{gathered}
$$


Drying of the beet-lemon mixture occurs (Figure 6, b) during the period of falling drying speed. The maximum drying rate of the red beetrootlemon mixture at a temperature of $100^{\circ} \mathrm{C}$ is 1.35 times greater than at a temperature of $60^{\circ} \mathrm{C}$.

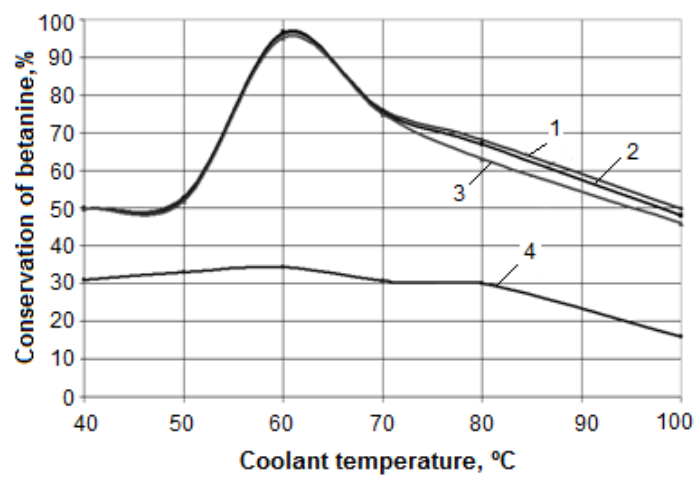

Figure 7. Preservation of betanine

from the type of raw material and coolant temperature:

1 - hygrothermal beet; 2 - rhubarb beet; 3 - lemon beet; 4 - beet

The dependences of betanine preservation on the coolant temperature are determined (Figure 7). The figure shows, that during the drying of betanine-containing raw materials without prior preparation at a coolant temperature of $40-50^{\circ} \mathrm{C}$, the preservation of betanin is $30-35 \%$. At a coolant temperature of $100^{\circ} \mathrm{C}$, betanine is stored only by $18 \%$. In the created composite mixtures of red beetroot-lemon and red beetroot-rhubarb (without hydrothermal treatment) during drying at a temperature of 40,50 and $100^{\circ} \mathrm{C}, 45-50 \%$ of betanine is stored. Developed hydrothermal treatment, creation of compositions of antioxidant raw materials, during drying gives the maximum preservation of betanine at the level of $95 \%$ at a temperature of the heat carrier of $60^{\circ} \mathrm{C}[11 ; 12]$.

Studies of phytoestrogenic raw materials were performed on whole soybeans, crushed and soybean-carrot compositions treated with hydrothermal. Soy contains a lot of phytoestrogens and in combination with carrots give the product a phytoestrogenic direction. 


\section{Chapter «Engineering sciences»}

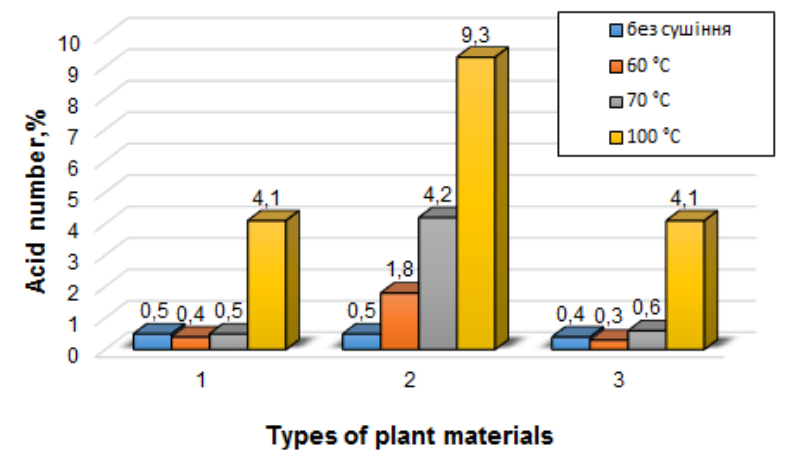

Figure 8. The increase in the acid number of phytoestrogenic raw materials under the action of coolant temperature: 1 - soy; 2 - chopped soybeans; 3 - soy-carrots

This raw material contains a large amount of fats $20-40 \%$, which in the process of processing are oxidized and destroy biologically active substances [13;14]. Therefore, the effect of coolant temperature during drying was investigated by determining the change in acid number. In soybeans in the process of drying from the temperature of the coolant, the change in the acid number occurs at $\mathrm{T}=100^{\circ} \mathrm{C}$. After grinding soybeans fats are oxidized at all these temperatures (Figure 8).

As can be seen from Figure 8 with increasing temperature of the coolant increases the acid number of soybean seeds. Thus, temperatures of $60,70^{\circ} \mathrm{C}$ have almost no effect on the change in acid number, and a temperature of $100^{\circ} \mathrm{C}$ increases the acid number by $7-14$ times.

Based on these data (Figure 8), developed modes of drying of phytoestrogenic raw materials, in which the temperature of the material does not exceed $70^{\circ} \mathrm{C}$.

Investigations of the dependence of folate storage to influence of coolant temperature during the drying of folate-containing raw materials are presented in Figure 9. Thus, increasing the temperature of the material has a negative effect on folic acid. In asparagus beans, as can be seen from Figure 9 , at a material temperature of $60^{\circ} \mathrm{C}$ we lose $60 \%$ of folate, and at a temperature of $100^{\circ} \mathrm{C}$ we lose 1.5 times more. 


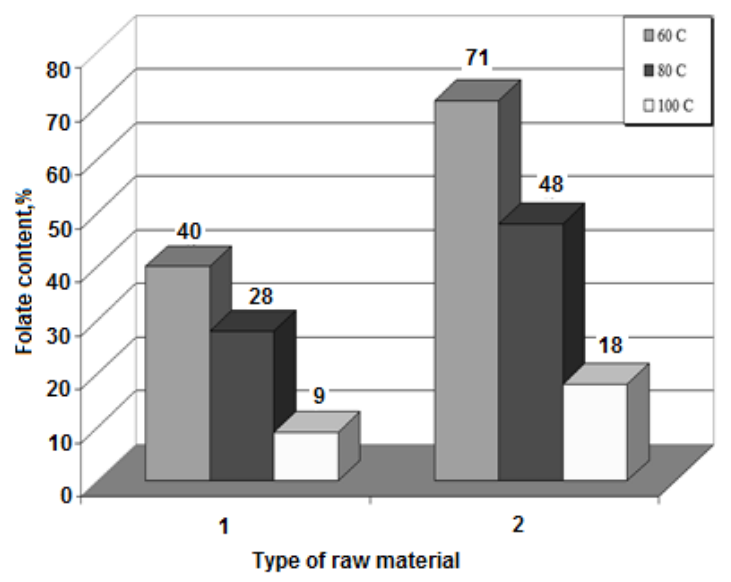

Figure 9. Preservation of folate depending on the type of folate-containing raw materials and coolant temperature: 1 - asparagus beans; 2 - asparagus beans - onions

When drying the composite mixture, asparagus beans - onion preserves folate $31 \%$ more than in asparagus beans. Even with increasing temperature of the material in the composite mixture, the content of folic acid compared to asparagus beans is higher, which indicates a successful combination of this mixture.

One of the main characteristics of dried raw materials is its swelling properties. The dynamic of the change of the swelling coefficient from the temperature of the coolant and the composite components of the functional raw material is presented in Figure 10.

At a temperature of the heat carrier $40-60^{\circ} \mathrm{C}$ the coefficient of swelling is the maximum and makes accordingly 5,6-7,1. With increasing coolant temperature, the coefficient of swelling decreases, which indicates a deterioration in the quality of the dried material. The coefficients of swelling of composite mixtures dried at a coolant temperature of $60^{\circ} \mathrm{C}$ compared to mono-raw materials are 1.25 times higher.

At the drying mode of $100 / 60{ }^{\circ} \mathrm{C}$ also high indicators of swelling and duration of dehydration at the same time are smaller with reduction of energy consumption. 


\section{Chapter «Engineering sciences»}

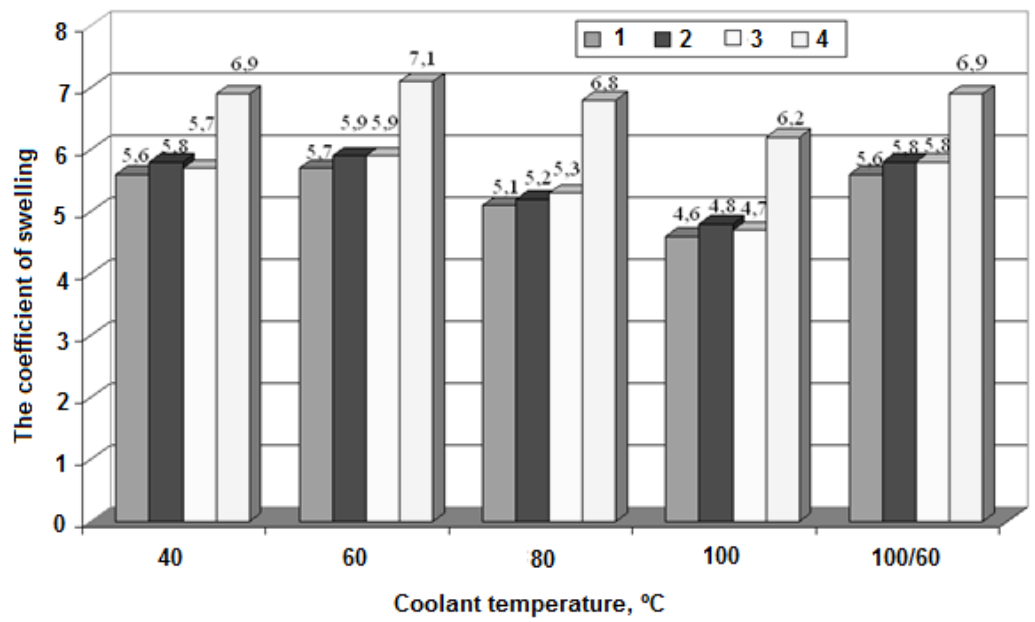

Figure 10. Influence of drying conditions

on the coefficient of swelling of functional raw materials: 1 - beet, 2 - hydrothermally treated beet, 3 - beet-lemon, 4 - beet-rhubarb

\subsection{Calorimetric studies of functional raw materials}

Since a significant increase in energy costs for drying is usually associated with the difficulty of removing moisture from plant material, the kinetics of dehydration due to the mobility of water molecules and the energy of their interaction with other molecules, the skeleton of the material, it was important to study changes specific heat of water evaporation from functional compositions.

The heat of evaporation of pure water is taken into account in calculations of duration of drying, and in raw materials it is a solution, which has absolutely other physicochemical and thermophysical properties. Therefore, it is important to determine the specific heat of vaporization.

To determine the specific heat of evaporation of functional raw materials using a differential microcalorimeter DMK1-01, developed at the Institute of Technical Thermophysics of the NAS of Ukraine [15].

Thin $(\sim 1 \mathrm{~mm})$ sections of parenchymal tissues of red beetroot and lemon were used for research. When calculating the energy costs for drying use 
the value of the specific heat of water evaporation. The practice of drying a number of complex plant materials indicates a significant difference between the actual values of the heat of evaporation of water from the heat of evaporation of pure water.

In Figure 11 shows the values of heat of evaporation of lemon, beet, beet-lemon composition and pure water, at a temperature $t=60{ }^{\circ} \mathrm{C}$, air velocity $v=0.4 \mathrm{~m} / \mathrm{s}$.

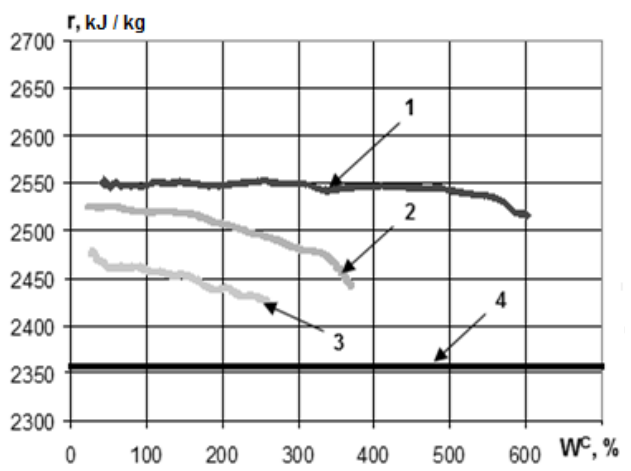

Figure 11. Comparative characteristics of the heat of evaporation of antioxidant raw materials based on red beetrot at a coolant temperature of $60^{\circ} \mathrm{C}$

1 - sliced lemon, 2 - sliced beet, 3 - mixture, 4 - water

Figure 12 shows that the beet-lemon mixture has 4-5\% less heat of evaporation in contrast to beets and lemon separately. The heat of evaporation from solutions differs from the heat of evaporation of pure water, and the heat of evaporation in the compositions is lower than in the mono-raw material.

The conducted experimental researches confirmed the theoretical assumption of dependence of specific heat of evaporation of water from parenchymal fabrics of plants on composite components of raw materials. The obtained results allow to state that at correctly picked up compositions they not only stabilize components of native raw materials, but also there is an intensification of drying process with reduction of energy consumption on process $[16 ; 17]$. 


\section{Conclusions}

According to the results of experimental research, energy-efficient pretreatment of vegetable raw materials for each group of functional products has been developed. The optimal drying regimes of functional raw materials are determined: antioxidant, phytoestrogenic, folate-containing and prebiotic. The heat of evaporation of water in some developed antioxidant plant compositions is less than the original components of the raw material. Energy-efficient step-by-step drying regimes of functional vegetable raw materials have been developed, in which the recoverability of dehydrated raw materials is $75-85 \%$, and energy consumption per $\mathrm{kg}$ of evaporated moisture is 2 times less than in existing single-stage modes. Losses of biologically active substances in the compositions during drying are less by $10-20 \%$ than in mono-raw materials.

\section{References:}

1. Shuljgha O. Kovbasa V., Sharan A., Petrova Zh. (2009). Jak zhe zminjujutjsja balastni rechovyny $\mathrm{v}$ ekstruzijnykh kartopleproduktakh pid chas ekstruziji [How do ballast substances in extruded potato products change during extrusion]. Khlibopekarsjka i kondytersjka promyslovistj Ukrajiny, no. 6, 22-24.

2. Petrova Zh.O., Sniezhkin Yu.F. (2018). Enerhoefektyvni teplotekhnolohii pererobky funktsionalnoi syrovyny. Kyiv: Naukova dumka, $187 \mathrm{~s}$.

3. Francis F.J. (1999). Colorants. Egan Press. ISBN 1-891127-00-4

4. Conversition Factors for Vitamin A and Carotenoids (2002). International Vitamin A Consultative Group. Washington, D.C: ILSI Press.

5. Sniezhkin Yu.F., Petrova Zh.O., Paziuk V.M. (2016). Energhoefektyvni teplotekhnologhiji vyrobnyctva funkcionaljnykh kharchovykh poroshkiv. Vinnytsia: VNAU, $456 \mathrm{p}$.

6. Sniezhkin Yu.F., Petrova Zh.O., Loveiko I.A., Getmanyuk K.M. (2009). Razrabotka tekhnologhyy funkcyonaljnogho pyshhevogho poroshka yz revenja y stolovoj svekly [Development of technology for functional food powder from rhubarb and beetroot]. Promyshlennaja teplotekhnyka, t. 31, no. 7, pp. 104-105.

7. Petrova Zh.O., Sniezhkin U.F., Getmanyuk K.M., Dmytrenko N.V., Vorontsov M.Ie. (2014). Intensyfying Drying Process with Creation of Functional Plant Compositions. Ukrainian Food Journal, vol. 3, issue 2, pp. 167-174.

8. Petrova Zh.O., Slobodianiuk K.S. (2019). Energy-efficient modes of drying of colloidal capillary-porous materials. Journal of Engineering Physics and Thermophysics, vol. 92, no. 5, pp. 1231-1238.

9. Schorah C.J. (1983). Critical glossary: folic acid. In: Dobbing J (ed) Prevention of Spina Bifida and other Neural Tube Defects. London: Academic Press, pp. 241-242.

10. Ito M., Kimura M., Deguchi Y., Miyamori-Watabe A., Yajima T., Kan T. (1993). Effects of transgalactjsylated disaccharides on the human intestinal flora and their metabolism. J Nutr Sci Vitaminol, t. 39, pp. 279-288. 
11. Petrova Zh.O., Sniezhkin U.F., Paziuk V.M., Samoilenko K.M. (2015). Drying of antioxidant composite materials based on table beet. Energy engineering and control systems, vol. 1, no. 1, pp. 25-28.

12. Petrova Zh.O., Paziuk V.M., Samoilenko K.M., Chepeliyk O.P. (2018). Effect of treatment modes on quality and antioxidant properties of tomato and beet processing products. Ukrainian food journal, vol. 7, issure 2, pp. 291-302.

13. St. Clair RW (1998). Estrogens and atherosclerosis: phytoestrogens and selective estrogen receptor modulators. Current Opinion In Lipidology, t. 9, pp. 457-463.

14. Adlercreutz H., Mazur W. (1997). Phytooestrogens and Western diseases. Annals of Medicine, vol. 29, pp. 95-120.

15. Kalorymetrychnyj prystrij dlja vyznachennja pytomoji teploty vyparovuvannja vologhy $\mathrm{i}$ orghanichnykh ridyn $\mathrm{z}$ materialiv: pat. 84075 Ukraine: МПК C12C 1/00. № a 200613266; zajavl. 15.12.2006; opubl. 10.09.2008; Bjul. 17-10 s.

16. Sniezhkin Yu.F., Petrova Zh.O., Dmytrenko N.V., Getmanyuk K.M. (2013). Doslidzhennja vplyvu poperednjogho komponuvannja roslynnoji syrovyny na jakistj sukhogho produktu ta teplotu vyparovuvannja [Investigation of the influence of pre-arrangement of vegetable raw materials on the quality of dry product and heat of evaporation]. Naukovi praci ONAKhT, vol. 43, t. 2, pp. 4-6.

17. Petrova Zh.O., Sniezhkin U.F., Samoilenko K.M (2015). Doslidzhennja teploty vyparovuvannja $\mathrm{z}$ betaninovmisnoji roslynnoji syrovyny v procesi znevodnennja metodom synkhronnogho teplovogho analizu [Investigation of evaporation heat from betanin-containing vegetable raw materials in the process of dehydration by the method of synchronous thermal analysis]. Naukovi praci ONAKhT, vol. 47, t. 2, pp. 33-38. 